\title{
Immunoglobulin concentration in mothers with leprosy and in healthy controls and their babies at the time of birth
}

\author{
R MELSOM, M E DUNCAN* \& G BJUNE \\ Institute for Experimental Medical Research, University of Oslo, \\ Ullevaal Hospital, Oslo 1, Norway; Armauer Hansen Research \\ Institute, Addis Ababa, Ethiopia and Medical Research Council, \\ Leprosy Project, Addis Ababa, Ethiopia
}

Received for publication 28 October 1979

\begin{abstract}
Summary Immunoglobulins were quantitated in sera from 52 matched mothers at delivery and in the corresponding cord blood samples. The cord IgA concentration was significantly increased in babies from mothers with active lepromatous leprosy compared to a control group, and a group where the mothers suffered from tuberculoid leprosy. The cord IgM concentration was normal both in babies from mothers with active lepromatous leprosy, the control group and the group of mothers suffering from tuberculoid leprosy. Since IgA does not cross the placenta, this increase reflects an active increased production of $\operatorname{IgA}$ in the foetus of mothers suffering from active lepromatous leprosy. This could indicate transfer of $M$. leprae or M. leprae antigens across the placenta into the foetus.
\end{abstract}

\section{Introduction}

In some maternal infections, namely rubella, cytomegalovirus infection, toxoplasmosis and syphilis, transplacental transfer of pathogens occurs (Alford, 1962; ${ }^{1}$ Scotti and Logan, 1968; $;^{2}$ McCracken and Shinefield, 1965) ${ }^{3}$ causing a severe generalized infection in the foetus. Under these circumstances, the foetus can start to produce antibodies in utero. This antibody production is sometimes indicated by increased IgM and/or IgA concentration in cord blood (Stiehm et al., 1966), ${ }^{4}$ and may be proven by specific antibodies of the IgM or Ig A class against the infectious agent (Scotti and Logan, 1968; Reimer et al., 1975). ${ }^{5}$

Up to the present time leprosy has not been demonstrated to cause intrauterine infection. The first clinical signs of manifest leprosy have been ${ }^{*}$ Present address: National Institute for Medical Research, Mill Hill, London.

Correspondence to: Dr R Melsom, University of Oslo, Institute for Experimental Medical Research, Ullevaal Hospital, Oslo 1, Norway.

$0305-7518 / 80 / 010019+28 \$ 01.00 / 0$ C 1980 British Leprosy Relief Association 
demonstrated at 1.5 to 2 years of age (Soul, 1958; ${ }^{6}$ Worth, 1960). ${ }^{7}$ Based upon these observations, it was generally thought that leprosy bacilli do not infect the foetus. The long incubation period before the appearance of definite clinical signs and symptoms has made the subject difficult to study.

A prospective study on the effect of leprosy on pregnancy, parturition and of the baby was carried out in Addis Ababa, Ethiopia, from 1975 to 1978. As part of this study, $\operatorname{IgA}, \operatorname{Ig} M$ and $\operatorname{IgG}$ were quantitated during pregnancy and at birth. We were especially interested in the increase of $\operatorname{IgM}$ and/or IgA concentration in cord blood as an indication of foetal exposure to $M$. leprae antigen(s).

\section{Materials and methods}

\section{PATIENTS}

Fifty-two pregnant women were selected for this study. All of them attended the outpatient clinic at the Addis Ababa Leprosy Hospital. The patients were clinically and histologically classified according to the Ridley-Jopling scale (Ridley and Jopling, 1966) ${ }^{8}$ and were divided into four groups.

\section{Group 1}

Seventeen mothers who suffered from lepromatous leprosy (LL-BL) with a positive bacterial index (BI), i.e. with acid fast bacilli in one or several skin smears taken from 6 different sites. All of them were treated with $100 \mathrm{mg}$ DDS daily.

\section{Group 2}

Five mothers who suffered from lepromatous leprosy with a negative BI (LL-BL). Four of these patients received DDS, 50 to $100 \mathrm{mg}$ daily, and had been on continuous treatment for at least 5 years. One patient had stopped treatment prior to the study.

\section{Group 3}

Sixteen mothers who suffered from tuberculoid leprosy (BT). Six patients still received DDS treatment (50-100 mg daily) and 10 patients were released from control before the trial started and did not receive any treatment.

\section{Group 4}

Fourteen mothers without any clinical sign of leprosy (NL), but with the same socio-economic background as the leprosy patients. 
The patients were divided into these 4 groups to separate the mothers with highly bacilliferous disease from the others, since the foetus in the first group would have the greatest chance of being exposed to $M$. leprae or their antigens. All the patients were Ethiopians living in the villages around the leprosy hospital under poor socio-economic conditions. Serum samples were obtained during the last trimester of pregnancy, and from the mother at delivery and from cord blood. The serum samples were stored at $-20^{\circ} \mathrm{C}$ and freeze dried before transportation to Norway. Prior to estimation of the immunoglobulin concentration, the sera were reconstituted with distilled water, and $0.01 \% \mathrm{NaN}_{3}$ was added as a preservative. They were subsequently stored at $+4^{\circ} \mathrm{C}$.

\section{IMMUNOLOGICAL METHODS}

Immunoglobulin concentrations were determined by the single radial diffusion technique (Mancini et al., 1964; Mancini et al., 1965; ${ }^{10}$ Fahey and McKelvey, $1965^{11}$ ) with specific anti-IgG, anti-IgA and anti-IgM (Dakopatts a/s, Copenhagen, Denmark) in 1\% Litex agarose gel (Litex a/s, Glostrup, Denmark) containing $0.05 \mathrm{M}$ barbiturate buffer of $\mathrm{pH}$ 8.6. The antisera were tested for specificity by immunoelectrophoresis and single radial diffusion using sera and isolated immunoglobulins from patients with myeloma and macroglobulinaemia, and sera from individuals with isolated lack of $\operatorname{IgA}$. The sera were found to be monospecific by these methods.

Immunoglobulins in the maternal sera were quantitated by the single radial diffusion method routinely used in our laboratory. A $1.5 \mathrm{~mm}$ thick agarose gel was made on a glass plate of $11 \times 20 \mathrm{~cm}$. The total volume of agarose gel on the plate was $44 \mathrm{ml}$ and the amount of anti-IgG $3.7 \mathrm{ml}$, i.e. $0.17 \mathrm{ml}$ anti-IgG/ $/ \mathrm{cm}^{2}$. In this plate, 66 wells were punched out with a diameter of $2 \mathrm{~mm}$. A volume of $5 \mu \mathrm{l}$ of either standard or sera to be tested was filled in the wells. Locally prepared $\operatorname{IgG}$ standard solutions were used and controlled at regular intervals against the Behringwerke's IgG standard (Behringwerke AG, Marburg, Frankfurt/M, Germany). The plates were left in a moist chamber at room temperature for $24 \mathrm{hrs}$. The precipitin rings had a sharply defined edge and were measured directly on the unstained plates.

The $\operatorname{IgA}$ and $\operatorname{IgM}$ concentrations in maternal sera were determined in the same way using $0.04 \mathrm{ml}$ anti-IgA or anti-IgM per $\mathrm{cm}^{2}$ gel. The Behringwerke $\operatorname{IgA}$ and $\operatorname{IgM}$ standards were used to prepare the standard curves.

The amount of $\operatorname{IgA}$ and $\operatorname{IgM}$ in cord blood is so low that it is difficult to determine the concentration by single radial diffusion methods (Papadatous et al., 1969:12 Evans et al., 1971 ${ }^{13}$ ). The technique was modified to ensure that minute amounts of $\operatorname{IgA}$ and $\operatorname{IgM}$ could be detected. The concentration of anti-IgA was lowered to $0.35 \mu \mathrm{l}$ anti- $\operatorname{IgA} / \mathrm{cm}^{2}$ in the agarose gel. At this point, weak but definite precipitin rings with sharply defined edges could be seen after staining with Coomassie brilliant blue when minute amounts of $\operatorname{IgA}$ were put in the wells. This concentration of anti-IgA in the gel was therefore chosen 
to detect $\lg \mathrm{A}$ in the cord sera. Wells with a diameter of $2 \mathrm{~mm}$ were made and filled with $5 \mu \mathrm{l}$ either standard or test sera. The plates were left in a moist chamber for $48 \mathrm{~h}$, washed and pressed 4 times, left for a final wash overnight, dried and stained with Coomassie brilliant blue. In this way distinct precipitin rings were obtained demonstrating IgA in concentrations down to $4 \times 10^{-3} \mathrm{~g} / \mathrm{l}$, and the $\operatorname{IgA}$ concentration could be determined if above $8 \times 10^{-3} \mathrm{~g} / \mathrm{l}$.

The concentration of IgM in the cord blood is 5 to 10 times higher than IgA (Faulkner and Borella, 1970;14 Hardy et al., 1969'15). It was therefore easier to determine the IgM concentration in cord blood. The agarose gel contained $0.7 \mu \mathrm{l}$ anti-IgM $/ \mathrm{cm}^{2}$. The plates were left at room temperature for $48 \mathrm{~h}$, washed and stained as for the Ig A plates. The standard used was diluted Behringwerke IgM standard.

For calculation of the statistical significance of difference between groups, Wilcoxon's modified ranking test was used (Documenta Geigy, 1962). ${ }^{16}$

\section{Results}

\section{IMMUNOGLOBULIN CONCENTRATION IN MATERNAL SERA AT} DELIVERY

The median $\operatorname{IgG}$ concentration in maternal sera at delivery was $8 \mathrm{~g} / \mathrm{l}$ with a range of $3 \mathrm{~g} / 1$ to $16 \mathrm{~g} / \mathrm{l}$. Figure 1 shows that there was no significant difference between the four groups of patients.

The median $\operatorname{Ig}$ A concentration was $1.24 \mathrm{~g} / 1$ with a range of 0.25 to $2.6 \mathrm{~g} / \mathrm{l}$.
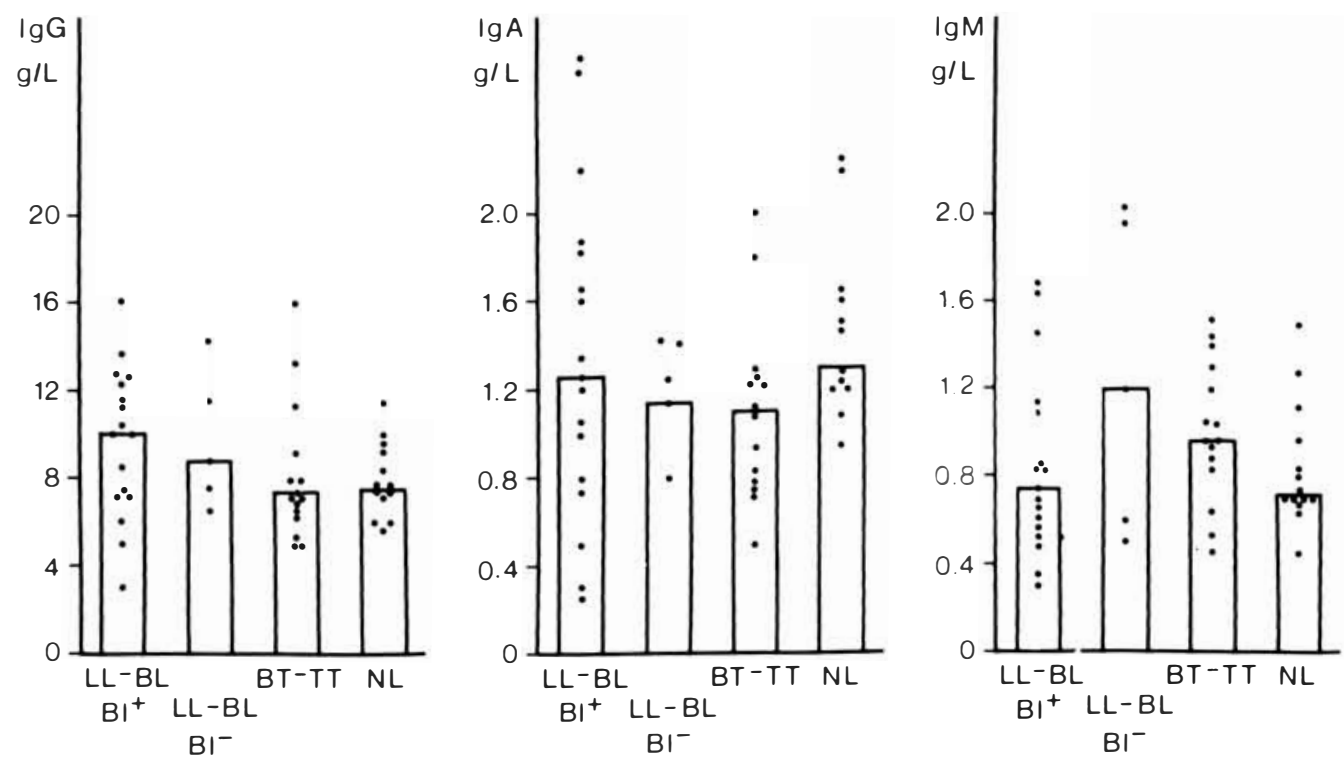

Figure 1. IgG, IgA and $\operatorname{IgM}$ concentration in maternal serum. Each point represents one individual and the top of the columns the median value. 
The median $\operatorname{IgM}$ concentration was $0.82 \mathrm{~g} / 1$ with a variation between 0.3 and $2.0 \mathrm{~g} / \mathrm{l}$. Neither IgA nor IgM concentration showed any significant difference between the four groups of patients, as shown in Fig. 1.

The IgG concentration in sera obtained from the mothers during the last three months of pregnancy was higher than at delivery. This fall of $\operatorname{lgG}$ concentration from pregnancy to delivery was observed in 24 out of 36 women. The 3 women with $\operatorname{IgG}$ concentration below $6 \mathrm{~g} / \mathrm{l}$ at delivery had $\mathrm{IgG}$ concentration below $6 \mathrm{~g} / \mathrm{l}$ when tested in the $3 \mathrm{rd}$ trimester.

\section{IMMUNOGLOBULIN CONCENTRATION IN CORD BLOOD}

Figure 2 shows the $\operatorname{IgG}$ concentration in the cord sera. The highest concentration was found in group 1 with a median value of $9.5 \mathrm{~g} / \mathrm{l}$, but there was no significant difference between the four groups. There was a good correlation between the $\operatorname{IgG}$ concentration in cord blood and maternal sera taken at delivery in each mother-baby pair. Out of 52 pairs, only 12 pairs showed a difference greater than $25 \%$ between the $\mathrm{IgG}$ concentration in cord blood and maternal blood taken at delivery.

The IgA concentration could be measured by single radial diffusion methods at levels above $8 \times 10^{-3} \mathrm{~g} / \mathrm{l}$. IgA could be detected if the concentration was above $4 \times 10^{-3} \mathrm{~g} / \mathrm{l}$, but it could not be quantitated at levels between 4 and $8 \times 10^{-3} \mathrm{~g} / \mathrm{l}$. These two limits are indicated on Fig. 3 with horizontal dotted lines. Out of 17 cord sera in group 1, two fell below the detection limit of $4 \times 10^{-3} \mathrm{~g} / \mathrm{l}$, while 12 out of 35 in group 2,3 and 4 fell below this limit. The median value of each group is indicated on Fig. 3 with a horizontal bar. Group 1 had a median value of $9.5 \times 10^{-3} \mathrm{~g} / 1$ while the median value of group 2, 3

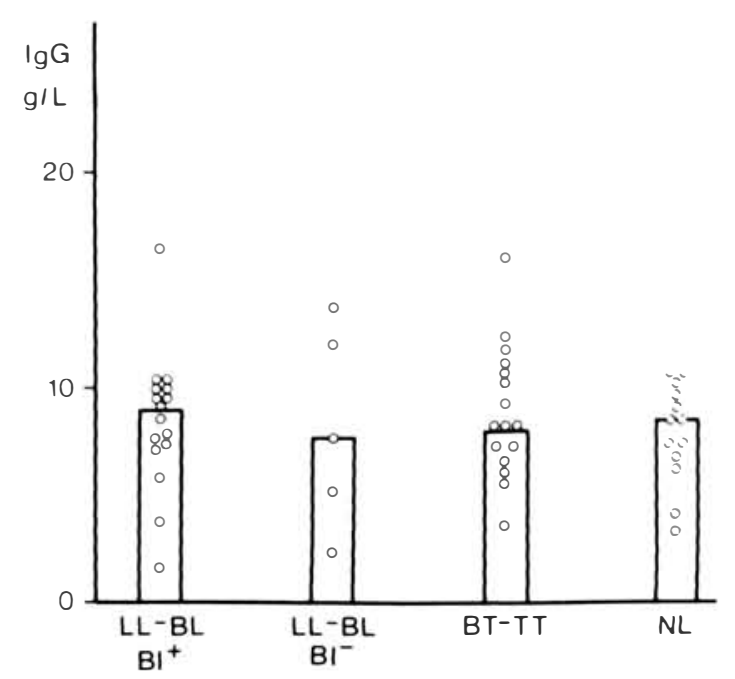

Figure 2. IgG concentration in cord serum, otherwise as for Figure 1. 
and 4 fell below $8 \times 10^{-3} \mathrm{~g} / \mathrm{l}$. This difference is significant using Wilcoxon's ranking test. The cord serum labelled 110 on Fig. 3 is excluded from the series because of possible leakage of maternal blood into this cord blood sample. The IgM concentration of this cord blood sample was $110 \times 10^{-3} \mathrm{~g} / \mathrm{l}$, and both the $\operatorname{IgA}$ and the IgM concentration was lower in a sample taken 6 weeks after birth from the same baby. In the other cord sera, there was no correlation between high concentration of $\operatorname{Ig} \mathrm{A}$ and $\operatorname{IgM}$, nor between $\operatorname{IgA}$ and $\operatorname{IgM}$ concentration in matched maternal and cord blood samples.

The IgM concentration in cord sera is shown in Fig. 4. The control group had the highest concentration with a median value of $74 \times 10^{-3} \mathrm{~g} / \mathrm{l}$, while the median value of the three other groups varied from 40 to $54 \times 10^{-3} \mathrm{~g} / \mathrm{l}$. These differences were not statistically significant $(p>0.1)$.

\section{Discussion}

Leprosy has not yet been described in patients below $1.5 \mathrm{yr}$ (Noussitou et al., 1976), ${ }^{17}$ in children it is still uncommon below the age of four, thus it is generally thought that leprosy is not transferred to the foetus.

Leprosy has an incubation time of 2 to 5 yrs (Newell, 1966) ${ }^{18}$ which can be partially explained by the slow multiplication rate of $M$. leprae (Shepard and McRae, 1965). ${ }^{19}$ After experimental inoculation of armadillo, more than 9

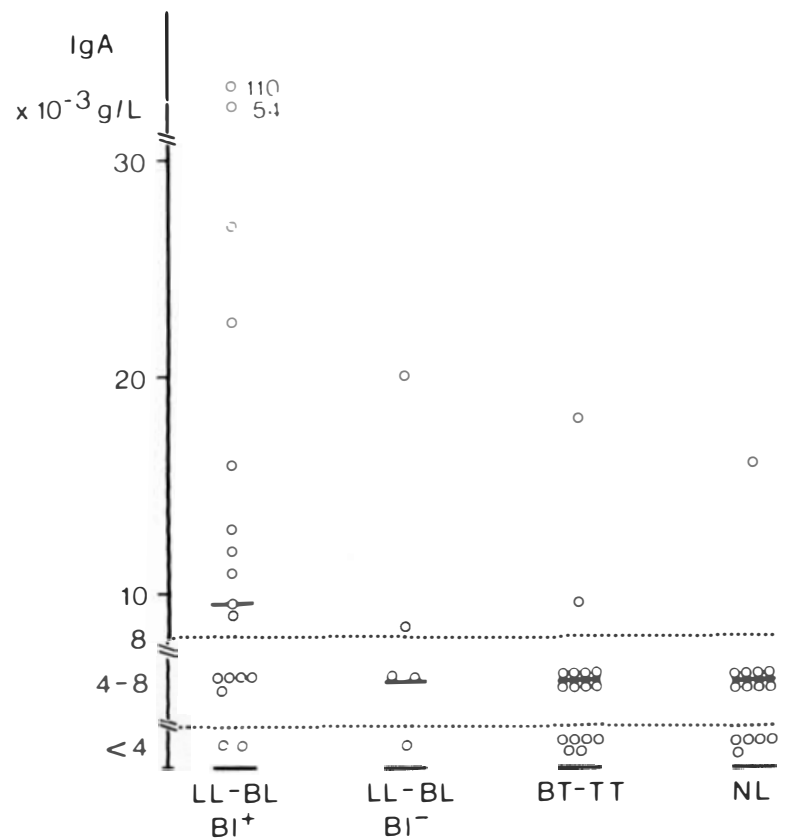

Figure 3. IgA concentration in cord serum. See text for explanation of the two horizontal dotted lines. The horizontal bars show the median value for the 4 groups. 


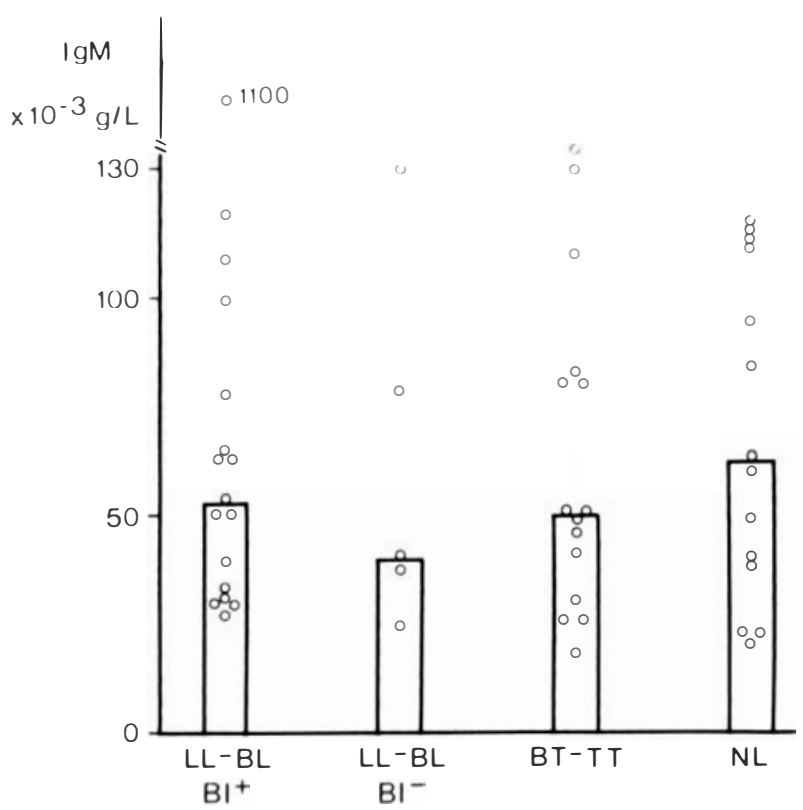

Figure 4. IgM concentration in cord serum, otherwise as for Fig. 1.

months elapsed before the leprosy bacilli had multiplied sufficiently to cause any clinical sign of leprosy (Kirchheimer and Storrs, 1971;20 Storrs, $1973^{21}$ ). The absence of published reports of leprosy in humans occurring within the first 1.5 years of life could be explained by the long incubation time even though the infection was acquired in utero.

Patients with active lepromatous leprosy, can have up to $10^{5}$ leprosy bacilli per $\mathrm{ml}$ of blood (Drutz et al., 1972). ${ }^{22}$ In pregnant women with active lepromatous leprosy, the exposure of the placenta to $M$. Leprae bacilli is intense and leprosy bacilli could cross the placenta and infect the foetus. However, soon after birth the newborn baby will be exposed to a heavy dose of M. leprae. The lepromatous leprosy mother can shed up to $2.4 \times 10^{8}$ leprosy bacilli from her nose in $24 \mathrm{~h}$ (Davey and Rees, 1974) ) $^{23}$ and leprosy bacilli can be present in breast milk (Pedley, 1967) ${ }^{24}$ The long incubation period of leprosy makes it impossible to decide if the baby was infected with leprosy before or after birth.

$\operatorname{IgG}$ crosses the placenta, therefore most of the $\operatorname{IgG}$ present in the cord blood has been made by the mother. The lower IgG concentration at parturation compared with that of the last trimester of pregnancy has been documented previously (Wagner and Knobloch, 1973;25 Maroulis et al., 197126). It is probably caused partially by active transport of $\mathrm{IgG}$ across the placenta and by increased catabolism in the mother around delivery.

$\operatorname{IgM}$ and $\operatorname{IgA}$ do not cross the placenta. Increased concentration of these 
immunoglobulins in cord blood could be taken as an indication of stimulation of the immune system of the foetus by transfer of antigen(s).

Increased $\operatorname{IgM}$ concentration in cord blood may be found in congenital infections such as syphilis, toxoplasmosis and cytomegalovirus infections but even in these diseases heavy congenital infections are not always associated with increased IgM concentration in cord blood (Reimer et al., 1975; McCraken et al., 1965; Hardy et al., 1969'5). Several workers have determined the lgM concentration in large numbers of cord sera and babies with abnormal IgM concentration were followed for clinical and serological signs of congenital infections. In many instances (from 60 to 80\%), babies with increased IgM concentration in cord blood could not be associated with any sign of congenital infection or disease during the first year of life (Hardy et al., 1969; ${ }^{15}$ Miller et al., 196927). Furthermore, intra-uterine infections such as syphilis and rubella do not always cause an increase in foetal IgM, therefore increased foetal IgM must be regarded as a non-specific and poor indicator of intra-uterine infection.

Little information is available regarding the IgA concentration in cord blood. In many instances, $\operatorname{IgA}$ has only been demonstrated in 5 to $10 \%$ of the cord sera examined. This has been due to insufficient sensitivity of the assay, the detection limit being 50-200 $\times 10^{-3} \mathrm{~g} / \mathrm{l}$ (Stiehm et al., 1966; ${ }^{4}$ Evans et al., 1971:13 Seth et al., 197128). Faulkner and Borella $1970^{14}$ developed a radioimmunoassay for quantitation of $\operatorname{IgA}$ in cord blood samples. They found that $\operatorname{IgA}$ was present in all cord sera tested in concentrations ranging from 1.5 to $25.5 \times 10^{-3} \mathrm{~g} / 1$ with a mean value of $8 \times 10^{-3} \mathrm{~g} / \mathrm{l}$. In our sera, we could determine $\operatorname{IgA}$ concentration down to $8 \times 10^{-3} \mathrm{~g} / \mathrm{l}$, and detect but not accurately quantitate down to $4 \times 10^{-3} \mathrm{~g} / \mathrm{l}$. IgA could be detected in 43 out of 52 cord sera we examined, and the concentration could be determined in 20 out of 52 sera. The median $\operatorname{IgA}$ cord concentration in our series is between 4 \& $8 \times 10^{-3} \mathrm{~g} / \mathrm{l}$. Our $\operatorname{IgA}$ cord blood concentrations are in agreement with the concentrations found by Faulkner and Borelli.

Increased IgA concentrations were demonstrated in cord blood from babies of mothers with active lepromatous leprosy (group 1). It is significant that at least 9 out of the 16 women in group 1 had an active relapse or were diagnosed as having lepromatous leprosy during this pregnancy. These women would have a large quantity of $M$. leprae bacilli in their blood stream throughout the pregnancy thus exposing the placenta, and possibly the foetus, to massive antigenic stimulation. The median cord $\operatorname{IgA}$ concentration in group 1 was $9.6 \times 10^{-3} \mathrm{~g} / \mathrm{l}$, while the median cord $\operatorname{IgA}$ concentrations in the three other groups $(2,3$ and 4) was below $8 \times 10^{-3} \mathrm{~g} / \mathrm{l}$. Cord $\operatorname{IgA}$ concentration was above $8 \times 10^{-3} \mathrm{~g} / \mathrm{l}$ in 9 samples out of 16 in group 1, while the cord IgA concentration was above $8 \times 10^{-3} \mathrm{~g} / \mathrm{l}$ in only 5 samples out of 35 from groups 2,3 and 4 . These differences are significant using Wilcoxon's ranking test. These results indicate that the immune system of the foetus was often stimulated when the mother suffered from active lepromatous leprosy. 
Other possibilities should also be considered. Leakage through the placenta could occur due to damage of the placenta in mothers with active lepromatous leprosy. The difference in IgA concentration in maternal and cord serum is great, about 500 times higher in the mother. A small placental leakage would lead to a marked increase in cord IgA concentration. Placental leakage ought to lead to simultaneous leakage of $\operatorname{IgM}$ and IgA. IgM concentrations in cord sera were normal, also in group 1. Except for one cord serum, marked 110 on Fig. 3 , we have found no indication that the increased $\operatorname{IgA}$ in cord blood from group 1 could be caused by leakage. The cord serum marked 110 has been excluded from the calculation due to possibility of placental leakage. The increased $\operatorname{IgA}$ concentrations in the other cord sera in group 1 must have been produced by the foetus before birth. This may have been caused by transfer of $M$. leprae or $M$. leprae antigen(s) across the placenta. Studies of the antigenic specificities of these babies' IgA will be studied later.

\section{Acknowledgements}

This work was supported by grants from the Norwegian Research Council for Science and the Humanities and Anders Jahre's Fund for the Promotion of Science.

\section{References}

1 Alford CA. Studies on antibodies in congenital rubella infection. Am J Dis Child, 1962, 110,445 .

2 Scotti AT, Logan L. A specific IgM antibody test in neonatal congenital syphilis. $J$. Pediat, 1968, 73, 242.

${ }^{3}$ McCracken GH, Shinefield HR. Immunoglobulin concentration in newborn infants with congenital cytomegalic inclusion disease. Pediat, 1965, 36, 933.

4 Stiehm ER, Ammann AJ, Cherry JD. Elevated cord macroglobulins in the diagnosis of intrauterine infections. New Eng J Med, 1966, 275, 971.

Reimer CB, Blake CM, Phillips DJ et al. The specificity of fetal IgM; antibody or antiantibody. Ann NY Acad Sci, 1975, 254, 77.

${ }^{6}$ Soul A. Lepra infantil; estudio de un caso tuberculoid. Dermatología (Mexico), 1958, 2, 45.

7 Worth RM. Leprosy in children born in Kalaupa. Hawaii Med J, 1960, 19, 403.

${ }^{8}$ Ridley DS, Jopling WH. Classification of leprosy according to immunity: A five-group system. Internat J Lep, 1966, 34, 255.

9 Mancini G, Vaerman J-P, Carbonara AO, Heremans JF. A single-radial-diffusion method for the immunological quantitation of proteins. Protides Biol Fluids, 1964, 11, 370-3.

10 Mancini G, Carbonara AO, Heremans JF. Immunochemical quantitation of antigens by single radial immunodiffusion. Immunochem, 1965, 2, 235.

11 Fahey JL, McKelvey EM. Quantitative determination of serum immunoglobulins in antibody-agar plates. J Immunol, 1965, 94, 84. 
12 Papadatous C, Papaevangelou G, Alexiou D, Mendris J. Immunoglobulin levels and gestational age. Biol Neonat, 1969, 14, 365.

13 Evans HE, Akpata O, Glass L. Serum immunoglobulin levels in premature and full term infants. Am J Clin Pathol, 1971, 56, 416.

14 Faulkner W, Borella L. Measurement of IgA levels of human cord sera by a new radioimmunoassay. J Immunol, 1970, 105, 786.

15 Hardy JB, McCracken GH, Mellits ED, Gilkeson MR, Sever JL. Serum immunoglobulin levels in newborn infants. J Pediat, 1969, 75, 1211.

16 Documenta Geigy. Basle: JR Greigy, SA, 1962.

17 Noussitou FM, Sansarricq H, Walter J. Leprosy in children Geneva: World Health Organization, 1976.

18 Newell KW. An epidemiologist's view of leprosy. Bull Wld Hlth Org, 1966, 34, 827.

19 Shepard CC, McRae DH. Mycobacterium leprae in mice: Minimal infectious dose, relationship between staining quality and infectivity, and effect of cortisone. J Bacteriol, $1965,89,365$.

20 Kirchheimer WF, Storrs EE. Attempts to establish the armadillo (Dasypus novemcinctus, Linn) as a model for study of leprosy. Int J Leprosy, 1971, 39, 693.

21 Storrs EE. Leprosy in the ninebanded arnadillo. Z Tropenmed Parasitol, 1973, 24, 53.

22 Drutz DJ, Chen TSN, Lu W-H. The continuous bacteremia of lepromatous leprosy. New England J Med, 1972, 287, 159.

23 Davey TF, Rees RJW. The nasal discharge in leprosy: Clinical and bacteriological aspects. Lepr Rev, 1974, 45, 121.

24 Pedley JC. The presence of M. leprae in human milk. Lepr Rev, 1967, 38, 239.

25 Wagner V, Knobloch V. Immunoglobulins under the influence of the non-specific factors. I. The influence of delivery on the $\operatorname{IgG}, \operatorname{IgA}$ and $\operatorname{IgM}$ levels in parturient women. $Z$ Immun Forsch Bd, 1973, 145, 313.

26 Maroulis GB, Buckley R, Yunger JB. Serum immunoglobulin concentrations during normal pregnancy. Am J Obst Gynec, 1971, 108, 971.

27 Miller JM, Sunshine PH, Remington JS. Quantitation of cord serum IgM and IgA as a screening procedure to detect congenital infection: Results in 5006 infants. J Pediat, $1969,75,1287$.

28 Seth P, Dasgupta A, Khandekar V. Immunoglobulin levels in cord serum. India J Path Bact, 1971, 14, 119. 